UDC 811.113.6+81`34

Elisabeth Zetterholm

Stockholm University

Åsa Abelin

University of Gothenburg

\title{
SWEDISH AND SOMALI LISTENERS' ATTITUDES TOWARDS L2 SWEDISH SPEECH
}

Foreign accented speech does not always have an impact on intelligibility. However, a foreign accent may have an impact on verbal communication even though the listener understands the message and this is often related to listeners' attitude. It is shown that listeners with the same first language (L1) rate their own accent more positively and comprehensible in comparison to listeners with other linguistic backgrounds. On the other hand, other studies show the opposite without any indication for intelligibility advantage for a speaker with the same first language as the listeners. Phonetic and phonological contrasts between languages also have an impact on foreign accent and the listeners' judgments concerning intelligibility and pleasantness. In this pilot study, the aim is to examine if Somali listeners rate speakers with a Somali accent of Swedish higher for intelligibility and pleasantness compared to native listeners of Swedish, and whether attitudes to L2 speech did or did not differ from one another.

Keywords: L2 Swedish, foreign accent, intelligibility, pleasantness, attitudes.

\section{Элисабет Цеттерхольм}

Стокгольмский университет

Оса Абелин

Гётеборгский университет

\section{ОЦЕНКА РЕЧИ ИНФОРМАНТОВ, ДЛЯ КОТОРЫХ ШВЕДСКИЙ ЯВЛЯЕТСЯ ВТОРЫМ ЯЗЫКОМ, ШВЕДАМИ И СОМАЛИЙЦАМИ}

Иностранный акцент не всегда имеет влияние на степень разборчивости речи. Тем не менее он может оказывать воздействие на вербальную коммуникацию, даже если слушатель понимает смысл сообщения, и этот факт связан с установками слушателей. Существуют доказательства того, что слушатели с общим 
родным языком (L1) дают более положительную и четкую оценку собственного акцента в сравнении со слушателями - носителями другого языка. Между тем в других исследованиях представлены противоположные результаты и отсутствуют какие-либо данные о том, что существуют преимущества в понимании при совпадении первого языка говорящего и слушающего. Фонетические и фонологические различия между языками также оказывают влияние на иностранный акцент и оценку разборчивости и «приятности» слушателями. Наше пилотное исследование направлено на изучение вопроса, насколько различается оценка разборчивости и «приятности» речи собеседников, для которых шведский является иностранным языком (в нашем случае - сомалийцев), в двух группах: сомалийцев и носителей шведского языка.

Ключевые слова: шведский как иностранный язык (L2), иностранный акцент, разборчивость речи, приятность речи, установки.

\section{INTRODUCTION}

Adult second language (L2) learners often speak with a foreign accent and many listeners can identify the speaker's first language by the accent [Moyer, 2013]. The speakers' degree of foreign accent is discussed as depending on different factors such as age of onset, length of residence, personality, motivation, experience of the target language and the learner's attitude towards the language and the culture [Abrahamsson, Hyltenstam, 2009; Derwing, Munro, 2015; Moyer, 2013]. M. J. Munro \& T.M.Derwing [1995] mention three dimensions useful when evaluating accented speech, namely: Intelligibility, defined as the extent to which an utterance is understood by a listener, comprehensibility, defined as how easy it is to understand utterances, accentedness defined as how strong the foreign accent is perceived by the listener. Studies have shown that there is no strong correlation between comprehensibility and accentedness according to ratings by native speaker listeners (e.g. [Derwing, Munro, 1997]). Therefore, a native-like pronunciation, without an accent must not be the goal for second language learners, but an intelligible speech is of importance for verbal communication to avoid misunderstandings. Native speakers judgments of accentedness often rely on suprasegmentals such as speech rate, pauses and sentence stress [Pickering, Baker, 2014]. L. Pickering \& A. Baker also point out sociocultural variables, such as the listener's attitude towards L2 speakers, which might affect the judgment of accentedness and comprehensibility.

L1 speakers' attitudes to L2 speakers can be formed from attitudes to cultural groups, but also from attitudes to L2 speech, regarding seg- 
ments, prosody or voice quality. Studies show that there are differences between languages average fundamental frequency and range (e.g. [Scherer 2000]). This is of importance when judging speakers of other languages since L2 speakers might be judged more positive or negative depending on the listeners' first language [Mennen, 2007]. Different languages can have a pervading high or low pitch level, which may give rise to attitudes to speakers by listeners from other languages (cf. [Mennen, Schaeffler, Docherty 2008]). Other languages can show different linguistic functions connected with final pitch rise; in those cases a too low or too high final pitch rise can be perceived as asking for information or as friendliness by listeners with a different L1 (cf. [Aronsson, 2015]). Thus if L2 speakers use the same prosody as in their L1 there might be misunderstandings in the conversation.

A study by S. Boyd, A. Abelin \& B. Dorriots [1999] showed that listeners' evaluations of a group of foreign born teachers' pedagogical skills correlates with perceived degree of foreign accent and with number of deviation tokens.

\section{THE AIM OF THE STUDY AND RESEARCH QUESTION}

The study presented here is a pilot study with the aim to get an idea about native and non-native listeners opinions about intelligibility and pleasantness in L2 speech as well as the listeners' attitude evaluations when listening to the speakers. Do listeners with the same L1 (Somali) as L2 speakers of Swedish rate the speech of the L2 speakers in the same way as L1 speakers of Swedish do?

\section{SHORT DESCRIPTION OF SWEDISH AND SOMALI LANGUAGES}

The Swedish language has nine distinctive vowel phoneme both concerning quality and quantity in stressed positions, six front /i y u e ø $\varepsilon /$ and three back /u o a/, according to G. Bruce [2010]. The Somali language has five basic vowel phonemes / i e a o / that occur in both a back and a front variant related to ATR, Advanced Tongue Root feature. Vowel quantity is contrastive in both languages. Swedish has 18 consonants and Somali 22 consonants. Following is not a complete description of the consonants, only a few are mentioned known as confusing when learning L2 Swedish. Three of the Swedish 
consonants are not represented as phonemes in Somali, namely /p v $\mathrm{y} /$, but /b/ and /f/ are phonemes both in Swedish and Somali [Bruce, 2012; Engstrand, 2004; Saeed, 1993]. In Swedish, word stress and the two word accents, accent 1 (acute) and accent 2 (grave) are distinctive features. Somali, on the other hand, has a tonal accent system with a high and a low tone related to morphological rules and grammatical categories [Hyman, 1981].

Earlier studies has shown that Somali speakers learning Swedish as their second language have problems with the distinction between the plosives /p/ and /b/ and the fricatives /f/ and /v/ [Zetterholm, Tronnier, 2017]. Many learners pronounce äpple (apple) [ $\varepsilon \mathrm{p}^{\mathrm{h}}: \mathrm{l}$ ] ] as [eb:lə] and vila (rest) [vi:la] is pronounced like [frl:a]. In the last example there is also a change in quantity between the vowel and the consonant. Acoustic analyses of the production of minimal pairs in Swedish show that learners with Somali as their first language pronounce the words with a distinctive vowel quantity contrast, as in Somali, but no quantity distinction in consonants, which is necessary in Swedish [Zetterholm, 2014].

\section{MATERIAL AND METHOD}

Ten adult Somali speakers learning Swedish as their second language were recorded reading sentences in Swedish. The sentences were prepared so that Swedish vowels and consonants as well as Swedish prosody were in contrast by using minimal pairs. Six male and four female speakers, aged 20-57 years participated. They had all lived in Sweden between 2-5 years and had been learning Swedish less than three years in the program Swedish for Immigrants. Their first language is Somali and only few of them have some knowledge about English. None of them are illiterate, but there is no information about their competence in reading and writing in either language. The recordings were made directly on a PC when the speakers read the sentences to their teacher in the classroom, not in a sound booth. However, all recordings have a quality useful for auditory and acoustic analyses.

A perception test was constructed in order to get an idea about Swedish and Somali listeners' opinion about intelligibility and their first impression in relation to pleasantness of the speakers, as well as the listeners' attitudes to the speakers. 11 Swedish listeners and 14 Somali 
listeners participated. The Somali participants practice as mother tongue instructors; the Swedish participants are all academics. We asked them to fill in a questionnaire when listening to the recordings from loudspeakers. They rated the speakers' intelligibility and pleasantness on a Likert scale 1-5. The questionnaire also has a multiples choice question with $12 \mathrm{op}$ tions as well as an open question about speaker characteristics. The optional words represent both positive and negative attitudes. In this study we stipulated the adjectives happy, surprised, trustworthy, energetic and polite as positive, and the adjectives boring, angry, sad, unreliable, tired and unfriendly as negative. The participants could mark as many adjectives as they wanted as well as using other words. This means that the number of answers will not be the same for all speakers. For the Somali participants, a native speaker translated the questionnaire to the Somali language.

The Swedish and the Somali participants listened to the 10 Somali speakers when reading one of the sentences each in Swedish. They all listened to the voices through loudspeakers and each recording was repeated once or twice. We asked the listener to judge intelligibility and therefore we did not want the listener to remember the meaning and the words, which might be the case if every speaker repeated the same sentence.

Acoustic analyses with measurements of the F0 range, maximum and minimum were done, using Praat [http://www.fon.hum.uva.nl/praat/]. Two trained phoneticians also did close auditory analyses with focus on speech tempo, loudness of speech as well as phonological errors. In this paper we will only present and discuss the acoustic and auditory results for three of the speakers in relation to judgments of intelligibility, pleasantness and attitudes to speakers.

\section{RESULTS}

The judgments on intelligibility for all the 10 speakers correlate for the Somali and Swedish listeners. The correlation is significant $r^{2}=0.418$, $p=0.0431$. Furthermore, none of the listener groups judged the speakers higher than the other; the difference between the Somali and the Swedish groups was not significant on a paired $t$-test, $p=0.7621$. There is also a significant correlation between the pleasantness judgments of the Somali and Swedish judgments: $r^{2}=0.4920, p=0.0238$. Furthermore, within each of the language groups there was a highly significant correlation between the speakers' judgments of intelligibility and pleas- 
antness, $r^{2}=0.9670$ for the Somali group and $r^{2}=0.9305$ for the Swedish group. This means that both language groups think that intelligible speech is more pleasant, when using a Likert scale $1-5$ for evaluation.

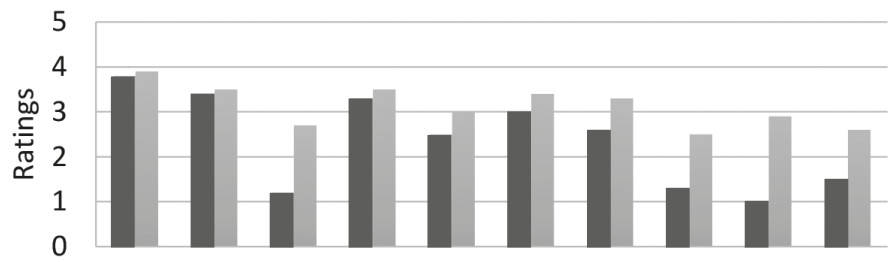

$\begin{array}{llllllllll}\text { Sp } 1 & \text { Sp } 2 & \text { Sp } 3 & \text { Sp } 4 & \text { Sp } 5 & \text { Sp } 6 & \text { Sp } 7 & \text { Sp } 8 & \text { Sp } 9 & \text { Sp } 10\end{array}$

n intelligibility pleasantness

Fig. 1. Mean values for judgments of intelligibility and pleasantness, Swedish listeners

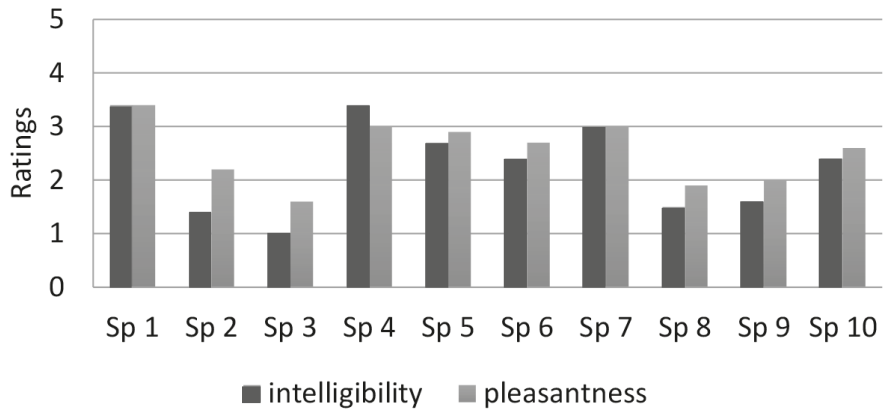

Fig. 2. Mean values for judgments of intelligibility and pleasantness, Somali listeners

In general, speakers got a higher rating concerning pleasantness, see Figure 1 and 2. Speaker 4 is an exception and got a higher rate on intelligibility than pleasantness from the Somali listeners. The Swedish and the Somali listeners did not always judge intelligibility and pleasantness in exactly the same way for individual speakers.

\section{DETAILED ANALYSIS OF THREE SPEAKERS}

Three of the speakers were chosen for narrow analyses. Acoustic analyses of F0 measures and auditory analyses for speech tempo, loud- 
ness of speech and phonological errors, were done for comparison with judgments of intelligibility, pleasantness and attitudes to speakers.

Speaker 1 and 3 got almost the same ratings in both language groups, but Speaker 2 was rated different in the two language groups. Speaker 1 (male) was rated high for intelligibility (3,8 and 3,4 respectively) and pleasantness (3,9 and 3,4 respectively) by the Swedish and the Somali listeners. Speaker 3 (female) was rated low for intelligibility (1,2 and 1 respectively) and pleasantness (2,7 and 1,6 respectively) by the Swedish and the Somali listeners. Speaker 2 (male) was rated high for intelligibility $(3,4)$ and for pleasantness $(3,5)$ by the Swedish listeners, but got a low rating for intelligibility $(1,4)$ and for pleasantness $(2,2)$ by the Somali listeners.

The results of the acoustic-auditive analyses are shown in Table 1. Speech tempo was judged as slow, medium or fast, loudness of speech as weak, medium or strong and when listening to phonological errors both segmental and prosodic errors were taken into account. There is a difference concerning F0 range where Speaker 2 has the lowest range and Speaker 3 the highest range. Speaker 1 has only few phonological errors, speaker 2 medium but speaker 3 has many phonological errors. Speech tempo is perceived as the same and loudness medium and weak respectively.

Table 1. F0 range, minimum and maximum (in $\mathrm{Hz}$ ), speech tempo, loudness of speech and phonological errors for speaker 1, 2 and 3

\begin{tabular}{|l|c|c|c|c|c|c|}
\hline & F0 range & F0 min & F0 max & tempo & loudness & $\begin{array}{c}\text { phonological } \\
\text { errors }\end{array}$ \\
\hline Speaker 1 & 55 & 77 & 132 & slow & medium & few \\
\hline Speaker 2 & 46 & 72 & 118 & slow & medium & medium \\
\hline Speaker 3 & 79 & 197 & 276 & slow & weak & many \\
\hline
\end{tabular}

This analysis indicates that many phonological errors is a predictor for negative judgments (on a Likert scale) on intelligibility and pleasantness, for both Somali and Swedish listeners.

\section{ANALYSIS OF ATTITUDE JUDGMENTS}

To get a closer look at the attitude judgments the number of chosen adjectives were measured for the three speakers. In the questionnaire the listeners could mark suggested adjectives or give other alterna- 
tives. The most frequently marked adjectives (numbers in brackets), the choice of positive or negative attitudes, and differences between Swedish and Somali listeners will be presented. A summary of the positive and negative evaluations is shown in Figure 3.

The attitude judgments for Speaker 1 were quite diverse. It seems that he was judged more negatively by the Somali listeners compared to the Swedish listeners. See Figure 3. Some of the negative adjectives got a higher score and more negative adjectives are mentioned among the Somali listeners. The highest score from Somali listeners was tired (6) and boring (4), from the Swedish listeners polite (6) and boring (3). Other adjectives used among Somali listeners are: trustworthy (3), slow, surprised, happy, polite, not trustworthy and negative (1 score each). The Swedish listeners assessed the speaker as: friendly (2), positive (2), tired, serious and indifferent (1 score each).

In the attitude judgments, where listeners assigned evaluative adjectives to the speech excerpts, Speaker 2 was more positively judged by the Somali listeners and quite negatively judged by the Swedish listeners overall, see Figure 3. However, there was a great variation within each listener group. The Somali listeners assessed the speaker as: happy (4), tired (3), positive (2), boring (2), trustworthy, surprised, energetic, unfriendly, not trustworthy, without energy (1 score each). The Swedish listener judged him: positive (4), tired (4), energetic (2), negative (2), meticulous, polite, boring, negative, uninterested, not trustworthy, bored (1 score each).

In the attitude judgments of Speaker 3 she was overall more negatively judged by the Somali listeners and more positively judged by the Swedish listeners, see Figure 3. A great variation within each listener group was shown also for this speaker. The Somali listener judged her as: boring (6), surprised (4), tired (2), negative (2) positive, energetic,
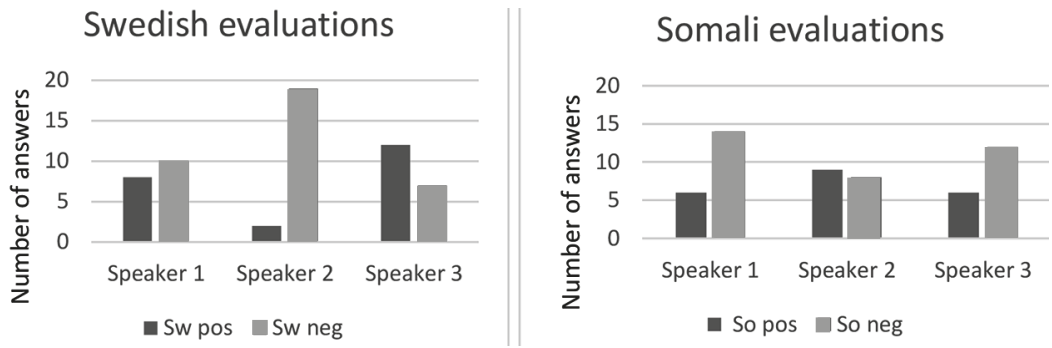

Fig. 3. Swedish and Somali listeners' evaluations of attitudes, speaker 1, 2 and 3 
angry, unfriendly ( 1 score each). The Swedish listener judged her as: boring (5), tired (5), negative (2), forced (2), unsure, positive, uninterested, impatient, nervous, sad, surprised (1 score each).

In Figure 3 it is obvious that there is a difference between Somali and Swedish listeners' evaluation in the attitude judgments. The most remarkable is the difference in judgments for Speaker 2. Connecting the evaluative adjectives with the results on intelligibility and pleasantness (on Likert scales), there are no obvious correlations with the evaluations. In addition, Speaker 2 was more positively judged in attitude, but negatively rated on intelligibility and pleasantness by the Somali listeners (and vice versa for the Swedish listeners).

\section{DISCUSSION AND FUTURE DIRECTIONS}

Judgments of intelligibility and pleasantness clearly correlate within each language group and between language groups. There is a tendency of correlation between intelligibility and phonological errors. The high scores on intelligibility and pleasantness for Speaker 1 correlate with few phonological errors and the low scores on intelligibility and pleasantness for Speaker 3 correlate with many phonological errors.

In general, the calculation of the answers on attitudes to speakers (the choice of adjectives) indicate that the positive and the negative attitudes to Speakers 1, 2 and 3 do not combine with any of the variables pleasantness or intelligibility, on a Likert scale. However there are individual variations. Speaker 2 has the lowest F0 range and that might have an influence on the low attitude evaluations of the Swedish listeners (Figure 3), but not that much for intelligibility or pleasantness on a Likert scale (Figure 1). One might also discuss how easy it is for listeners to differentiate between intelligibility and pleasantness, since there were no further explanations of these concepts in the test.

Further analyses of more speakers and listeners are needed before definitive conclusions can be drawn on the topic of what phonetic and phonological features cause problems of intelligibility and attitudes to speakers in L2 Swedish pronunciation.

\section{REFERENES}

Abrahamsson N., Hyltenstam K. Age of onset and nativelikeness in second language: Listener perception versus linguistic scrutiny. Language Learning, 2009, vol. 59(2), pp. 249-306. DOI: 10.1111/J. 1467-9922.2009.00507.x. 
Aronsson B. Transfer of rising tone patterns from Swedish L1 into Spanish L2 which are the communicative consequences? Working Paper 55, Proceedings of Fonetik, 2015. Lund University, pp. 17-21.

Boyd S., Abelin Å., Dorriots B. Attitudes to foreign accent. Proceedings from Fonetik 99, GPTL 81. Göteborg, 1999, pp. 31-35.

Bruce G. Var fonetiska geografi. Om svenskans accenter, melodi och uttal. Lund: Studentlitteratur, 2010.239 s.

Bruce G. Allmän och svensk prosodi. Lund: Studentlitteratur, 2012. $160 \mathrm{~s}$.

Derwing T.M., Munro M. J. Accent, intelligibility, and comprehensibility: Evidence from four L1s. Studies in Second Language Acquisition, 1997, vol. 19(1), pp. 1-16. DOI: 10.1017/s0272263197001010

Derwing T.M., Munro M.J. Pronunciation Fundamentals. Evidence-based Perspectives for L2 Teaching and Research. Amsterdam/Philadelphia: John Benjamins Publishing Company, 2015. 208 p.

Engstrand O. Fonetikens grunder. Lund: Studentlitteratur, 2004. 355 s.

Hyman L. M. Tonal accent in Somali. Studies in African Linguistics, 1981, vol. 12, pp. 169-203.

Mennen I. Phonological and phonetic influences in non-native intonation / eds J.Trouvain, U.Gut. Non-Native Prosody. Phonetic Description and Teaching Practice (Trends in Linguistics. Studies and Monographs [TiLSM] 186). Berlin, New York: Mouton de Gruyter, 2007, pp. 53-76.

Mennen I., Schaeffler F., Docherty G. A methodological study into the linguistic dimension of pitch range differences between German and English / eds P. A. Barbosa, S. Madureira, C. Reis. Proceedings of the fourth Conference on Speech Prosody, 2008, pp. 527-530.

Moyer A. Foreign Accent. Cambridge University Press, 2013. 218 p.

Munro M. J., Derwing T. M. Processing Time, Accent and Comprehensibility in the Perception of Native and Foreign-Accented Speech. Language and Speech, 1995, vol. 38(3), pp. 289-306.

Pickering L., Baker A. Suprasegmental measures of accentedness / eds J.Levis, A. Moyer. Social Influences in L2 Pronunciation. DeGruyter Mouton, 2014, pp. $75-96$.

Praat: doing phonetics by computer. Available at: http://www.fon.hum.uva.nl/ praat/ (accessed: 28.12.2014).

Saeed J.I. Somali Reference Grammar. Kensington, Dunwoody Press, 1993. $313 \mathrm{p}$.

Scherer K. A cross-cultural investigation of emotion inferences from voice and speech: implications for speech technology. Proceedings of the $6^{\text {th }}$ International Conference on Spoken Language Processing, 2000. Beijing 2, pp. 379-382.

Zetterholm E. Vowel length contrast and word stress in Somali-accented Swedish. Proceedings of the International Symposium on the Acquisition of Second Language Speech. Concordia Working Papers in Applied Linguistics, 2014, vol. 5, pp. 771-782. 
Zetterholm E., Tronnier M. Perspektiv på svenskt uttal. Fonologi, brytning och didaktik. Lund, Studentlitteratur, 2017. $176 \mathrm{s.}$

For citation: Zetterholm E., Abelin Å. Swedish and Somali listeners' attitudes towards L2 Swedish speech. Scandinavian Philology, 2017, vol. 15, issue 2, pp. 193-203. https://doi.org/10.21638/11701/spbu21.2017.203

\section{Elisabeth Zetterholm}

Doctor of Philisophy, Associate Professor,

Universitetsvägen 10 E, 11418 Stockholm, Sweden

E-maill: elisabeth.zetterholm@isd.su.se

\section{Åsa Abelin}

Professor, $\mathrm{PhD}$,

General Linguistics,

Olof Wijksgatan 6, 41255 Göteborg, Sweden

E-mail: asa.abelin@ling.gu.se 